\title{
Prevalence of Sickle Cell Disease among Newborns in St Vincent and the Grenadines: A Retrospective Study
}

\author{
S Williams ${ }^{1}$, B Browne ${ }^{2}$, S Reed ${ }^{1}$, S Taylor ${ }^{1}$, A Summer $^{1}$, J Kanter ${ }^{1}$
}

\begin{abstract}
Objective: In the United States of America (USA), sickle cell disease (SCD) occurs in 1:375 African-American births. However, published data from the Caribbean have revealed higher numbers for some Caribbean islands. St Vincent and the Grenadines (SVG) is a multi-island nation in the Caribbean, and there are currently no data on the incidence or prevalence of the disease in this population. The objective of this study was to obtain birth prevalence estimates for $S C D$ in $S V G$.

Methods: A retrospective review of haemoglobin electrophoresis test results at the laboratory of the main hospital in SVG for the period of October 1, 2005 to December 31, 2013 was done. Test results and demographic data were extracted to determine the estimated birth prevalence of SCD.

Results: The estimated birth prevalence of SCD was found to be 1:172 live births, and $86 \%$ of the patients were diagnosed after one year of age.

Conclusion: The birth prevalence of SCD in SVG was higher than those in the USA, but was similar to the numbers in other Caribbean populations.
\end{abstract}

Keywords: Birth prevalence, newborn screening, sickle cell disease

\section{Prevalencia de la enfermedad de células falciformes entre los recién nacidos en San Vicente y las Granadinas: Un estudio retrospectivo}

S Williams ${ }^{1}$, B Browne ${ }^{2}$, S Reed ${ }^{1}$, S Taylor ${ }^{1}$, A Summer ${ }^{1}$, J Kanter ${ }^{1}$

\begin{abstract}
RESUMEN
Objetivo: En los Estados Unidos de América (EE.UU.), la enfermedad de células falciformes (ECF) ocurre en 1:375 de los nacimientos de afroamericanos. Sin embargo, los datos publicados en el Caribe revelan un número mayor para algunas islas del Caribe. San Vicente y las Granadinas ( $S V G$ ) es una nación formada por varias islas en el Caribe, y actualmente no existen datos sobre la incidencia o prevalencia de la enfermedad en esta población. El objetivo de este estudio fue obtener estimados de la prevalencia de nacimientos con ECF en SVG.

Métodos: Se realizó una revisión retrospectiva de los resultados de pruebas de electroforesis de hemoglobina en el laboratorio del hospital principal de $S V G$, correspondientes al periodo de 1 de octubre de 2005 a 31 de diciembre de 2013. Los resultados de la prueba y los datos demográficos se obtuvieron para hacer un estimado de la prevalencia de nacimientos con ECF.
\end{abstract}

From: ${ }^{1}$ Medical University of South Carolina, Charleston SC, United States of America and ${ }^{2}$ Milton Cato Memorial Hospital, Kingstown, St Vincent and the Grenadines, West Indies.
Correspondence: Dr S Williams, Medical University of South Carolina, Charleston SC, United States of America. Email: williasp@ musc.edu 
Resultados: Se halló que la prevalencia estimada de nacimientos con ECF fue de 1:172 por nacidos vivos, y que el $86 \%$ de los pacientes fueron diagnosticados después de un año de edad. Conclusión: La prevalencia de nacimientos con EFC en SVG fue más alta que la de los EE.UU., pero similar a las estadisticas en otras poblaciones del Caribe.

Palabras clave: Prevalencia de nacimientos, tamizaje neonatal, enfermedad de células falciformes

West Indian Med J 2017; 66 (4): 487

\section{INTRODUCTION}

Sickle cell disease (SCD) results from a mutation in the beta-globin gene of haemoglobin $(\mathrm{Hb})$ and is one of the most common inherited diseases worldwide (1). Although most common among people of African descent, it is seen in many other populations due to population migration (1-3). In the United States of America (USA), which has universal newborn SCD screening, SCD is identified in one out of every 375 AfricanAmerican infants (4). However, many countries in the Caribbean have a higher estimated birth prevalence of SCD and yet, do not have universal newborn screening programmes for SCD. For example, Jamaica has demonstrated a birth prevalence of SCD as high as 1:150 births with a limited newborn screening programme (5).

Newborn screening for SCD allows for early diagnosis and the opportunity to initiate early preventative treatment. Universal newborn screening for SCD was initiated in the USA after the pivotal prophylactic penicillin study (PROPS) demonstrated reduced infections and a subsequent reduction in mortality (6). Newborn screening, coupled with a paediatric comprehensive care programme, has been shown to decrease early childhood mortality as well as disease morbidity not only in the USA, but also in other worldwide populations $(5,7-9)$.

St Vincent and the Grenadines (SVG) is a nation that comprises an archipelago of islands with a total population of approximately 110000 and approximately 1700 births per year (10). There are no newborn screening programmes in SVG.

There are no published data on the prevalence or birth prevalence of SCD in SVG. The objective of this study was to obtain birth prevalence estimates for SCD in SVG using the local available data in order to assess whether a pilot newborn screening programme should be conducted in this population.

\section{SUBJECTS AND METHODS}

This study was approved by the Institutional Review Board of the Medical University of South Carolina and the National Ethics Review Committee of the Ministry of Health, Wellness and the Environment in SVG.

A cross-sectional study of $\mathrm{Hb}$ electrophoresis results from the laboratory at the Milton Cato Memorial Hospital (MCMH) was performed. This laboratory is the only one in SVG that performs $\mathrm{Hb}$ electrophoresis and, as such, is the only laboratory in SVG where SCD can be diagnosed. Haemoglobin electrophoresis results are not recorded electronically but are written in a laboratory results book. The earliest results available in the written record were the results beginning on October 1, 2005. Thus, $\mathrm{Hb}$ electrophoresis results from October 1 , 2005 to December 31, 2013 were reviewed.

For the results that were positive for SCD, the patients' date of birth (DOB), age at time of test and test results were extracted. It was anticipated that there would be patients for whom a DOB was not recorded; therefore, it was decided a priori that the DOB would be extrapolated for those patients based on their age at the time of the test. Extrapolated DOBs were calculated as if the patient was at the exact age given at the time of the test. For the patients who were $\geq 1$ year of age at the time of the test, the DOB was calculated as if the child was exactly $x$ years and zero month old. Therefore, the DOB was estimated by assigning the test result day and month as the patient's birth day and month. For patients who were $<1$ year of age, the DOB was calculated as if the child was $x$ months and zero day old at the time of the test. To ensure that the patients were not counted twice, we included the initial test results and excluded subsequent tests for the patients with the same name and DOB. However, for patients where the DOB was extrapolated, we excluded repeat tests for the patients with the same name, gender and result, if the year of birth was the same. The patients with no demographic information documented were excluded from our analysis.

In the absence of a universal newborn screening programme, it was expected that the patients would be diagnosed symptomatically and at later ages. Studies of the clinical presentation of SCD showed that 
disease-specific symptoms were seen in $96 \%$ of the patients with HbSS by the age of eight years, but were seen in only about $75 \%$ of the patients with $\mathrm{HbSC}$ by the age of eight years $(11,12)$. Based on this information and the available $\mathrm{Hb}$ electrophoresis data, the estimation of the SCD birth prevalence for those patients born in 2006 and 2007 was chosen. These patients would be the oldest patients in the data set and would allow for the inclusion of patients with a late diagnosis, thereby improving the accuracy of our estimates.

The number of live births in 2006 and 2007 was obtained through the local Vital Statistics Department in SVG, and birth prevalence was estimated as: the number of patients born in 2006 and 2007 and diagnosed during the study period (therefore diagnosed $<8$ years) divided by the number of live births in SVG during 2006-07.

\section{RESULTS}

In this study, there were 21 children who were born between January 1, 2006 and December 31, 2007 and had positive results for SCD ie were diagnosed with SCD during the study period (Fig. 1). Of those with SCD, $67 \%(14 / 21)$ were diagnosed with homozygous SS disease and 33\% (7/21) with SC disease. The earliest age at diagnosis was at eight months of age, and $86 \%(18 / 21)$ of the patients were diagnosed at one year of age or older. Figure 2 shows the frequency by age at diagnosis for these patients. The total number of live births for 2006 and 2007 was 1796 and 1822, respectively. The estimated average birth prevalence for SCD for the years 2006 and 2007 combined was calculated as 1:172 live births.

\section{DISCUSSION}

It was estimated from this study that for the years 2006 and 2007, 1:172 Vincentian newborns were diagnosed with SCD. In addition, the results showed that there were significant delays in the diagnosis as the majority of the patients were diagnosed over the age of one year, which is older than is recommended. A delayed diagnosis results in deferred initiation of penicillin prophylaxis which increases morbidity and mortality (13).

The estimated 1:172 Vincentian newborns with SCD was within the expected range based on similar reports from other nations in the Caribbean. Published data from geographically-related regions where limited or universal newborn screening for SCD exists estimated ratios for birth prevalence as high as 1:150 in Jamaica, 1:173 in Haiti and 1:304 in Guadeloupe. These were all higher

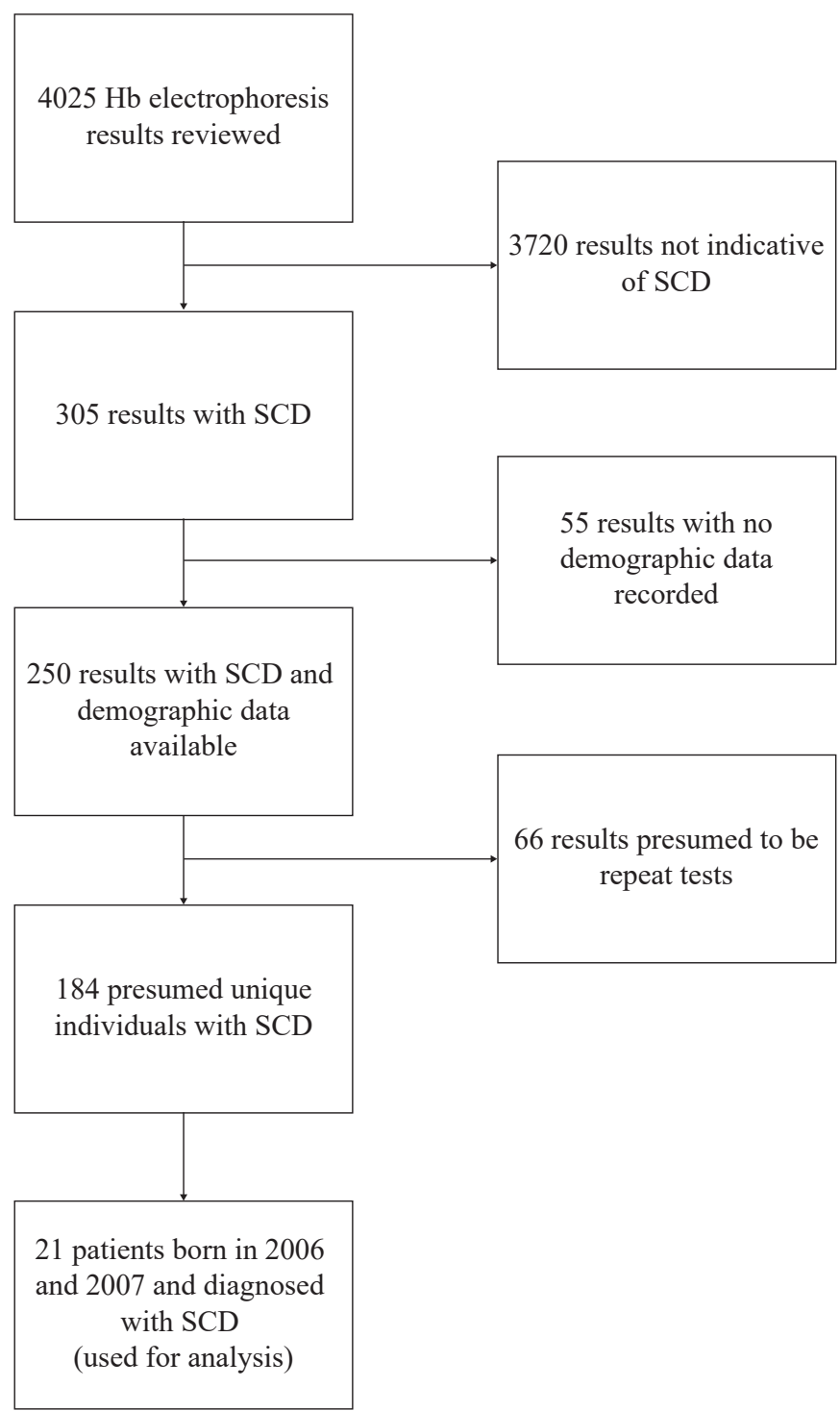

Fig. 1: Flow diagram of the study population SCD stands for sickle cell disease and includes patients with HbSS and $\mathrm{HbSC}$.

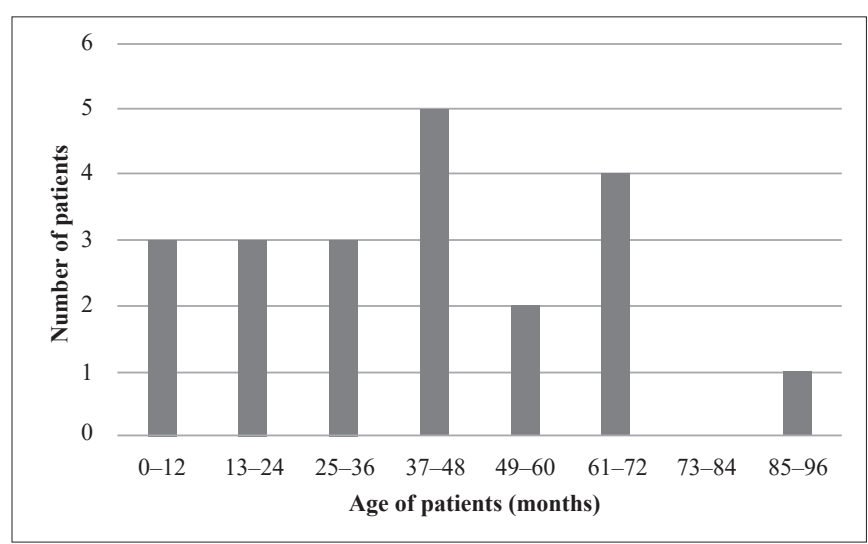

Fig. 2: Frequency by age at diagnosis for patients born in 2006 and 2007 and diagnosed during the study period $(\mathrm{n}=21)$. 
than the 1:375 for African Americans in the USA (4, 5, $8,14)$.

These estimates were limited by the extrapolation of DOB, the use of handwritten records and our lack of mortality records. For the patients included in the analysis, only $9.5 \%$ ( 2 of the 21 patients) had a documented $\mathrm{DOB}$, and therefore the DOB was extrapolated in most cases. In addition, the lack of mortality data would likely influence the results of this study in estimating the true birth prevalence of SCD. It is well known that SCD is associated with early childhood mortality (9). With no access to mortality data, it was possible that young patients had died prior to undergoing testing or diagnosis and were not included in the counts. Furthermore, it is possible that there might have been patients diagnosed at later ages outside of the study period which might also lead to an underestimation of birth prevalence estimates.

In the absence of a newborn screening programme or a population-based surveillance system, a cross-sectional approach using existing data was the only option to estimate birth prevalence. Fortunately, this study had a single source of data, the central laboratory at the MCMH which is the only laboratory in SVG capable of diagnosing SCD. This precluded missing additional persons which is possible when using hospital utilization data which might be biased to a sicker population and miss counting healthier persons (15). This was a strength as the counts were all confirmed SCD cases. This singular source of data also decreased the chance of missing data because the patients were diagnosed from testing at this laboratory.

Despite the significant morbidity and mortality caused by SCD, the improvements in early diagnosis and management have significantly improved outcomes. Key enhancements include early initiation of prophylactic penicillin, pneumococcal immunization, parental education and close monitoring $(5,6,16,17)$. Data from regions of Sub-Saharan Africa have shown that patients are at a $50 \%$ risk of death prior to five years of age if not diagnosed and managed appropriately $(18,19)$. These data confirmed the need for newborn screening to avoid preventable early mortality and morbidity. In 2006, the World Health Organization stated that analyses of the treatments for haemoglobin disorders had demonstrated that specialized centres and newborn screening programmes were cost-effective approaches to improving outcomes for SCD and thalassaemia (19). Therefore, in developing nations where the burden of the disease is high, universal newborn screening along with comprehensive care is needed (20).
This study was the first to determine estimates for the birth prevalence of SCD among newborns in SVG and thus contributes to the emerging data on the birth prevalence of SCD in the Caribbean. The estimates were similar to those of the other countries in the region, all of which were higher than those of the USA where universal newborn screening for SCD exists. Despite the contributions made to the field of SCD by the work done in Jamaica, the Caribbean continues to lag behind in the implementation of newborn screening programmes for $\operatorname{SCD}(21,22)$. Given the relatively high estimated numbers of Vincentian newborns affected by SCD and the delays in their diagnosis, there is the need to pilot a universal newborn screening programme. This would give more accurate birth prevalence estimates and determine the feasibility and cost effectiveness of a newborn screening programme in this population.

\section{ACKNOWLEDGEMENTS}

We would like to thank the Ministry of Health, Wellness and the Environment of SVG and the laboratory at the MCMH for access to the data.

This project was funded in part by a pilot grant through the Center of Global Health at the Medical University of South Carolina and Award Number UL1TR000062 from the National Center for Research Resources of the USA. The content is solely the responsibility of the authors and does not necessarily represent the official views of the National Center for Research Resources or the National Institutes of Health of the USA.

\section{REFERENCES}

1. Wang Y, Kennedy J, Caggana M, Zimmerman R, Thomas S, Berninger $\mathrm{J}$ et al. Sickle cell disease incidence among newborns in New York State by maternal race/ethnicity and nativity. Genet Med 2013; 15: 222-8.

2. Manu Pereira M, Corrons JL. Neonatal haemoglobinopathy screening in Spain. J Clin Pathol 2009; 62: 22-5.

3. Piel FB, Hay SI, Gupta S, Weatherall DJ, Williams TN. Global burden of sickle cell anaemia in children under five, 2010-2050: modelling based on demographics, excess mortality, and interventions. PLoS Med 2013; 10: e1001484.

4. Lin K, Barton MB. Screening for hemoglobinopathies in newborns: reaffirmation update for the U.S. Preventive Services Task Force. U.S. Preventive Services Task Force evidence syntheses, formerly systematic evidence reviews. Rockville (MD) 2007.

5. King L, Fraser R, Forbes M, Grindley M, Ali S, Reid M. Newborn sickle cell disease screening: the Jamaican experience (1995-2006). J Med Screening 2007; 14: 117-22.

6. Gaston MH, Verter JI, Woods G, Pegelow C, Kelleher J, Presbury G et al. Prophylaxis with oral penicillin in children with sickle cell anemia. A randomized trial. New Engl J Med 1986; 314: 1593-9.

7. Le PQ, Ferster A, Cotton F, Vertongen F, Vermylen C, Vanderfaeillie A et al. Sickle cell disease from Africa to Belgium, from neonatal screening to clinical management. Medicine tropicale: revue du Corps de sante colonial 2010; 70: 467-70. 
8. Saint-Martin C, Romana M, Bibrac A, Brudey K, Tarer V, DivialleDoumdo L et al. Universal newborn screening for haemoglobinopathies in Guadeloupe (French West Indies): a 27-year experience. J Med Scree 2013; 20: 177-82.

9. Vichinsky E, Hurst D, Earles A, Kleman K, Lubin B. Newborn screening for sickle cell disease: effect on mortality. Pediatrics 1988; 81: 749-55.

10. Pan American Health Organization. Health in the Americas: regional outlook and country profiles 2012 (cited December 7, 2014). Available from: http://www1.paho.org/saludenlasamericas/docs/hia-2012-summary.pdf.

11. Bainbridge R, Higgs DR, Maude GH, Serjeant GR. Clinical presentation of homozygous sickle cell disease. J Pediatr 1985; 106: 881-5.

12. Williams S, Maude GH, Serjeant GR. Clinical presentation of sickle cell-hemoglobin C disease. J Pediatr 1986; 109: 586-9.

13. Overturf GD, Powars D, Baraff LJ. Bacterial meningitis and septicemia in sickle cell disease. Am J Dis Child 1977; 131: 784-7.

14. Rotz S, Arty G, Dall'Amico R, De Zen L, Zanolli F, Bodas P. Prevalence of sickle cell disease, hemoglobin S, and hemoglobin C among Haitian newborns. Ame J Hematol 2013; 88: 827-8.

15. Paulukonis ST, Harris WT, Coates TD, Neumayr L, Treadwell M, Vichinsky E et al. Population based surveillance in sickle cell disease: methods, findings and implications from the California registry and surveillance system in hemoglobinopathies project ( $\mathrm{RuSH})$. Pediatr Blood Cancer 2014; 61: 2271-6.
16. Lee A, Thomas P, Cupidore L, Serjeant B, Serjeant G. Improved survival in homozygous sickle cell disease: lessons from a cohort study. BMJ 1995; 311: 1600-2.

17. Hamideh D, Alvarez O. Sickle cell disease related mortality in the United States (1999-2009). Pediatr Blood Cancer 2013; 60: 1482-6.

18. Grosse SD, Odame I, Atrash HK, Amendah DD, Piel FB, Williams TN Sickle cell disease in Africa: a neglected cause of early childhood mortality. Am J Prev Med 2011; 41 (6 Suppl 4): S398-405.

19. Weatherall D, Akinyanju O, Fucharoen S, Olivieri N, Musgrove P. Inherited disorders of hemoglobin. In: Jamison DT, Breman JG, Measham AR, Alleyne G, Claeson M, Evans DB et al, eds. Disease control priorities in developing countries. 2nd ed. New York: Oxford University Press; 2006.

20. Ansong D, Akoto AO, Ocloo D, Ohene-Frempong K. Sickle cell disease: management options and challenges in developing countries. Mediterr J Hematol Infect Dis 2013; 5: e2013062.

21. King L, Knight-Madden J, Reid M. Newborn screening for sickle cell disease in Jamaica: a review - past, present and future. West Indian Med J 2014; 63: 147-50.

22. Serjeant GR. Jamaica, the Caribbean and sickle cell disease. West Indian Med J 2012; 61: 331-7. 